tiolence

\title{
Religion, Government Coalitions, and Terrorism
}

\author{
Nil S. Satana , Molly Inman \& Jóhanna Kristín Birnir
}

To cite this article: Nil S. Satana, Molly Inman \& Jóhanna Kristín Birnir (2013) Religion, Government Coalitions, and Terrorism, Terrorism and Political Violence, 25:1, 29-52, DOI: 10.1080/09546553.2013.733250

To link to this article: https://doi.org/10.1080/09546553.2013.733250

册 Published online: 07 Dec 2012.

Submit your article to this journal

III Article views: 1731

4 Citing articles: 8 View citing articles 


\title{
Religion, Government Coalitions, and Terrorism
}

\author{
NIL S. SATANA \\ Department of International Relations, Bilkent University, \\ Bilkent, Ankara, Turkey

\section{MOLLY INMAN} \\ Department of Government and Politics, University of Maryland, \\ College Park, College Park, Maryland, USA

\section{JÓHANNA KRISTÍN BIRNIR} \\ Department of Government and Politics; and Center for International \\ Development and Conflict Management (CIDCM), University of \\ Maryland, College Park, College Park, Maryland, USA
}

\begin{abstract}
When ethnic minority parties are excluded from government coalitions, are group attributes such as religion related to the groups' use of political violence? We argue that extremist factions within minority groups make use of divergence in religion to mobilize support for violent action when the group is excluded from government. Thus, we posit that while religion per se is not a source of violence, extremist elements of ethnic minorities, whose religion differs from the majority, may use religious divergence to mobilize group members to perpetrate terrorism. Specifically we test the hypotheses that extremist factions of an excluded group will be more likely to carry out terrorist attacks when the group's members belong to a different religion as well as when they belong to a different denomination or sect of a religion than the majority. To test these propositions, we use data on ethnic minority party inclusion in government coalitions, ethnic minority group religion, and the Global Terrorism Database (GTD) by matching perpetrators with ethnic groups for all democracies, 1970-2004.
\end{abstract}

Keywords electoral politics, extremism, minority groups, political access, religion, terrorism

Nil S. Satana is an assistant professor in the Department of International Relations at Bilkent University. She received her PhD from the Department of Political Science at the State University of New York at Buffalo. Molly Inman is a PhD candidate in the Department of Government and Politics at the University of Maryland. Jóhanna Kristín Birnir is an associate professor in the Department of Government and Politics at the University of Maryland and the research director of the Center for International Development and Conflict Management (CIDCM).

Address correspondence to Nil S. Satana, Department of International Relations, Bilkent University, Bilkent 06800 Ankara, Turkey. E-mail: nsatana@bilkent.edu.tr 


\section{Introduction}

On May 11, 2010, "a man with explosives strapped to his body blew himself up in a crowd, bombers struck a southern city and gunmen sprayed fire on security checkpoints in attacks that killed at least 100 people - most of them in Shiite areas - in Iraq's deadliest day of the year." Iraq's former Shi'i Vice President Adel Abdul-Mahdi called for "quickly forming a government that does not exclude any major political group" to prevent perpetrators of terrorism from "exploiting Iraq's fragile security." 2 Efforts to form a coalition government that included religious minority representation in a democratizing and divided Iraq proved futile in the wake of the March 7, 2010 elections. Prime minister Nouri al-Maliki's Shi'i bloc chose to exclude from the coalition another Shi'i leader, Ayad Allawi-a secular politician supported mainly by Sunnis in the country. Consequentially, Sunni terrorist attacks increased both in intensity and casualties in the months following the election. ${ }^{3}$

This story is not very different than that of India or other democracies where elections, the first and foremost element of liberal democracy, do not necessarily guarantee the representation of religious minority groups in legislative coalitions and disgruntled minority groups on occasion resort to violence to voice their political demands. ${ }^{4}$ This article addresses the questions of whether and how a group's attributes are related to its propensity for alternative political expression, including violence. We examine the role of one such attribute-religion - in influencing a group's use of violence, specifically terrorism, in democracies worldwide.

Although secularization has been a major trend, especially in industrial and post-industrial states, "religion remains more strongly and more consistently related to voting choice today than any of the various indicators of socioeconomic status." Nevertheless, there is a dearth of cross-national empirical studies that examine the relationship between religion and party politics ${ }^{6}$ especially with respect to the incidence of political violence. ${ }^{7}$ Similarly, while the literature on coalition formation is very rich, ${ }^{8}$ few scholars address the relationship between religion and coalition-formation ${ }^{9}$ especially as it pertains to the incidence of terrorism and political violence. ${ }^{10}$

Previous work examining the effect of religion on coalition formation questions "what effect ethnic minority constituency religion has on the probability that the minority gets invited to join in an executive coalition" "11 by the majority political party. ${ }^{12}$ Findings suggest that in democracies ethnic majority politicians strategically consider collaboration with ethnic minorities of various religious backgrounds, perhaps to signal their commitment to diversity. In this article, we build on the argument that religious minorities are treated differently by the majority parties in coalition-building. We turn the question on its head and examine the actions taken by ethnic groups of a different religion than the majority when they are excluded from government.

One potential political action - the one that we explore in this article-is terrorism. Sandler defines terrorism as "the premeditated use, or threat of use, of extra-normal violence or brutality to gain a political objective through intimidation or fear of a targeted audience." 13 Following Sandler's definition, we assume that terrorism is one tool that extremist members of ethnic groups can use to influence domestic political incentives to their advantage. Consequently, we argue that when excluded from coalitions, extremist elements of ethnic minorities may consider terrorism as one way to press for their policy preferences when these groups are excluded from the governing coalition. 
Terrorism is an extreme tool to use in politics. Thus, to mobilize even a segment of the minority in support of such radical action, extremists may suggest that exclusion by the majority is not simply routine politics but a more nefarious attempt at cultural marginalization. Religion is an important and highly salient cultural attribute. Therefore, it is reasonable to expect extremist factions of excluded ethnic groups to use religious divergence between majorities and minorities to mobilize minority support for the use of extreme tactics such as terrorism. It is important to note, however, that we are focusing on the difference in religion and its impact on choice of political expression when excluded, not on the level of religiosity of any particular group, majority or minority.

Building on this expectation, we propose some testable hypotheses about the effect of exclusion of ethnic groups, which are also religious minorities, from governing coalitions on the probability of terrorist attacks by their extremist elements. We test our theory on ethnic minority access to legislative coalitions and the incidence of terrorism across democracies worldwide between 1970 and 2004. To do this, we use data on government coalitions and religion ${ }^{14}$ merged with the Global Terrorism Database (GTD) by matching perpetrators of terrorism with ethnic groups for all democracies worldwide. ${ }^{15}$ In sum, our empirical results show that the less access to the government an ethnic group subscribing to a different religion than that of the majority population has, the more likely its extremist elements are to engage in terrorism. Importantly, we also find that it is not absolute religious difference that motivates extreme political action. When excluded from government, ethnic minorities belonging to a different religious denomination or sect than the majority are also more likely to engage in terrorism as compared to ethnic groups that belong to the same religion and denomination as the majority.

\section{Literature and Theory}

In the first section we examine the role of religion in electoral politics. We then discuss the strand of the literature on elections, which deals with ethnic minorities and electoral outcomes as well as resorting to violence. We find that although past work acknowledges the continued importance of religion on every aspect of electoral politics from voting to cabinet formation, the existing literature offers little guidance as to how minority religion might play a role in electorally motivated violence. We then turn to the terrorism literature, in particular the literature on the fourth wave, which discusses the role of religion on violence at length. We build on the insights of this literature regarding the role of religion as an intervening variable in motivating terrorism. Specifically, we use the idea of religion as an institution that is ripe for politicization to formulate hypotheses regarding the relationship between minority religion, coalition formation, and terrorism.

\section{Religion, Party Politics, and Coalition Formation}

Ernest Gellner posits that apart from societies that are predominantly Muslim, the "secularization thesis does hold." 16 On the other hand, according to Norris and Inglehart, secularization is a myth both earlier in history as "differences between Protestants and Catholics in Western Europe functioned as a cognitive shortcut, like the role of social class which linked voters to parties," and in contemporary world politics. ${ }^{17}$ In fact, the literature on electoral politics indicates that religion plays a 
role in the construction of public policy agendas by political parties. Moreover, religion helps to stabilize votes in maturing democracies in the long run. ${ }^{18}$ In contrast to Gellner's argument, religion still remains an important determinant of voters' political views in highly developed countries such as the United States. ${ }^{19}$

Green, for instance, examines the relationship between religion and the U.S. party system in the 1990s and finds that "religious groups were important elements of the stable political coalitions that undergird routine politics. In the 1990s, each of the major parties had strong religious constituencies." 20 Hence, the Republican Party was mostly supported by traditionalists, such as Evangelicals, while the Democrats drew support from ethnic and religious minorities. As a result, "each party was able to build winning electoral coalitions by reaching beyond its core constituency." ${ }^{21}$ In line with this argument, the effect of religion on electoral politics and more specifically coalition politics does not necessarily manifest itself through "self-identified religious parties." Wittenberg suggests that the impact of religion in party politics is apparent in the support for secular parties whose constituency includes religious and ethnic groups. ${ }^{22}$ Rosenblum agrees that the "distinction between religious parties and religious party organizations allied to secular parties is not crucial, so long as religious political groups are constituent elements of the party as demonstrated by candidate recruitment, platforms and programs, strategy, coalition building, and so on."23

While this literature concurs with the point of view that religion clearly affects party politics and coalition formation, few scholars have examined the effect of religious identity on access to the government. ${ }^{24}$ Most states in the post-Westphalia nation-state system are heterogeneous. Accordingly, states that are electoral democracies often include ethnic minority parties whose constituency religion differs from the religion of the majority.

In a democracy, the expectation is that all minorities have a chance of inclusion in the government, where they might have a more direct effect on their groups' socioeconomic and political position. Lijphart argues that power-sharing institutions increase the accommodation of groups' interests and prevent conflict. ${ }^{25}$ Moreover, Birnir asserts that when the expectation to improve a minority ethnic group's position through access to governing coalitions is unfulfilled, the frustration of a minority may lead to violence. ${ }^{26}$ Although she does not address the effect of religion in this equation, many ethnic minorities differ in terms of religious affiliation from the majority in the country where they reside.

In the following section, we elaborate upon why we expect extremist elements of minorities whose religion differs from the majority, more than members of other minority groups, to resort to violence in the form of terrorism when the group is excluded from direct political access. Building on Rosenblum, we suggest that political inclusion of the religiously distinct ethnic minority does not have to occur through an explicitly religious party. Rather we focus on the religion of the minority constituency represented by ethnic political parties to understand the role of minority religion in coalition politics. In other words, when a political party appeals for votes from a particular religious minority (as well as other ethnic groups), we assume that the party cannot distance itself from the religious beliefs of that constituency. For example, Jammu and Kashmir Democratic People's Party in India is an ethnic party that appeals to the ethnic Kashmiri minority; however, it is also a party that appeals to Muslims in India who are not ethnic Kashmiri. Thus, the party does not distance itself from the general Muslim population despite its 
Kashmiri roots. The party gets votes from Muslims, in general, as well as ethnic Kashmiris, who are also typically Muslim.

\section{Religion, Political Access, and Terrorism}

A popular view of the contemporary relationship between religion and terrorism is the "new terrorism" literature. As summarized by Weinberg, Pedahzur, and Hirsch-Hoefler citing Rapoport, Hoffman, and others, "this 'new' or fourth wave of terrorism has been dominated by religious concerns, and especially Islamist ones." 27 Moreover, "by contrast to its predecessor(s), the new terrorists have been willing to inflict mass casualties, kill large numbers of people, and use or attempt to use unconventional weapons to achieve this end." 28

A primordial interpretation of this descriptive relationship is that the immediate motivations of terror are found in religious doctrine or beliefs. ${ }^{29}$ According to Hoffman, for example, "whereas secular terrorists attempt to appeal to actual and potential sympathizers, religious terrorists appeal to no other constituency than themselves," and according to Cronin, "religious terrorists act directly or indirectly to please the perceived commands of a deity." 30 Rapoport adds that "sacred terror" has common characteristics, regardless of how different religions are from each other. ${ }^{31}$ In sum, as Hasenclever and Rittberger argue, Primordialists link religious traditions directly to political conflict. ${ }^{32}$

An alternative view argues that while religion per se is generally not the cause of conflict, it adds a troubling dimension to extant conflict. According to Juergensmeyer, for example, the sources of intergroup tension are usually economic and social in character; "at some point in the conflict, however, usually at a time of frustration and desperation, the political contest becomes religionized. Then what was primarily a secular struggle takes on the aura of sacred conflict. This creates a whole new set of problems." 33 Juergensmeyer adds that all religions, including Christianity, Judaism, Islam, Hinduism, Sikhism, and Buddhism, experience and perpetrate violence. When the perpetrators of violence perceive themselves and their way of life as under attack, "an odd attraction between religion and violence" emerges. ${ }^{34}$

Similarly, Fox posits that religion becomes a salient political issue when the group harbors desires for autonomy or independence. ${ }^{35}$ Seul and Fox suggest that religion provides a framework that helps people understand the world around them. ${ }^{36}$ Fox further argues that when challenged, the reality provided by this framework must be defended. He also suggests that religious frameworks provide codes of conduct for adherents. In some cases, these codes are even thought to require conflictual behavior by followers. Thus, both Seul and Fox agree that religious institutions may facilitate conflict, and Fox adds that religious authority grants the conflict legitimacy. Additionally, Stark underscores the strength of the world-shaping view of religion. ${ }^{37}$ In sum, these instrumentalist arguments maintain that extremists use religion as a tool to reach their desired aims. ${ }^{38}$

In fact, referring specifically to Islam, Sedgwick suggests that while the ultimate aims of "new terrorists" belonging to the fourth wave, including Al-Qaeda, may be religious, they are similar to other terrorist groups in that their immediate goals are political. ${ }^{39} \mathrm{He}$ argues that what distinguishes the constituency of Al-Qaeda from constituencies of nationalist or leftist movements that must work to encourage national or class consciousness is that "an Islamic movement can skip this stage, 
since its chosen constituency-Muslims - is already very conscious of its existence; it only needs to be made into a political constituency." 40

Relevant to our research question, the terrorism literature also addresses the role of political structures in motivating terrorist attacks. For example, it pursues the issue of whether democracies are more susceptible to terrorism than authoritarian states, ${ }^{41}$ whether political parties and elections are related to the incidence of terrorism, ${ }^{42}$ and whether violence is particularly acute around elections. ${ }^{43}$ Indridason, for example, argues that terrorism is likely before elections and finds that the 2004 attacks in Spain three days before the Spanish legislative elections led to the demise of the People's Party (PP), since people believed that the PP was not able to provide sufficient security to prevent such attacks. ${ }^{44}$

Building on Birnir's argument that ethnic groups will be frustrated when they are excluded from government, ${ }^{45}$ we argue that it is not elections per se that lead to violence. Nor do we argue that minority groups are excluded because of their religion. Previous research on this topic finds that the content of religion does not matter for inclusion in legislative coalitions. In fact, minorities that subscribe to a different religion than the majority are more likely to be invited to join coalitions than other minorities. ${ }^{46}$ However, as is the case with other minorities - it stands to reason that minorities who do not subscribe to the same religion as the majority also become increasingly "frustrated" after a new coalition that excludes them. Furthermore, governing coalitions tend to change around elections.

Assuming Indridason is correct in that "terrorism results in the formation of larger and more ideologically cohesive coalitions," 47 we expect that some excluded minorities will consider violence as an effective strategy to influence future coalition building and thereby their own chances of being included. We posit that for minorities whose religion differs from the majority, resorting to terrorism will be at least as viable an option to achieve the group's goals as it is for other excluded minorities.

The question that remains is whether extreme factions within minorities that diverge in religion from the majority are more likely than are other minorities to choose terrorism as a strategy. Our argument builds on Juergensmeyer and Sedgwick's idea that although politics are the immediate concern, disgruntled groups use religion as a tool to mobilize and justify violence. ${ }^{48}$ Specifically, we suggest that when excluded from central governance, minority/majority cultural distance provides the minority group with a uniquely mobilizable platform for radical action. Such a cultural divide may be linguistic, racial, based on customs, or any other distinguishing feature of the ethnic minority group. Generalizing Sedgwick's insights about Islam to other religions, we add that a distinct minority religion is perhaps the most salient of such cultural divides, because it tends to provide a ready issue platform that does not depend on prior political mobilization. Religion is a divide that can be mobilized politically when needed. On average, therefore, we would expect that the cultural distance of adhering to a distinct religion improves the mobilizing capabilities for radical violence by extremists within ethnic minority groups beyond that of minority groups who share a common religion with the majority. For example, in India, the now-defunct Jammu and Kashmir Islamic Front, an extremist organization within the Muslim Kashmiri minority group, perpetrated a terrorist attack in 1989 after Muslim Kashmiris were excluded from the Hindu majority government for several years. The Hindu majority had been reluctant to include Kashmiri political parties in the government before the attack and religious extremists used the opportunity to mobilize violence in support of the Kashmiris' rights. 
In this context, it is important to emphasize that the perpetration of terrorist acts, as opposed to other types of political violence such as guerilla insurgency, generally requires only a small number of member adherents. Also important, we are not arguing that minority groups whose religion diverges from the majority are any more radical than minority groups who share a religion with majorities. In contrast, we suggest that divergence in religion provides extremists with an issue platform on which to mobilize for radical action in the context of exclusion. Thus, we hypothesize that:

Hypothesis 1 (H1): When excluded from access to government, extremist elements of minority ethnic groups that diverge from the majority population with regard to religion are more likely to perpetrate terrorist attacks as compared to ethnic groups who share a religion with the majority group.

Importantly, we would highlight that we are focusing on groups that do have some level of political representation in the legislature but which are excluded from the governing coalition. This is relevant because it goes beyond theories, which suggest that the mere granting of political representation should quell political violence.

Our next conjecture delves deeper into the content of the religious divide. Ben-Dor and Pedahzur show that since the early 1990s the number of terrorist attacks by Islamist groups roughly follows the pattern by other terrorist groups. ${ }^{49}$ The number of victims in terrorist attacks perpetrated by Islamist groups has, however, been higher than that of other terrorist groups. ${ }^{50}$ Ben-Dor and Pedahzur make the case that this difference is due to the unique characteristics of Islamic terrorist groups that are not shared by other religiously motivated terrorist groups. Sedgwick, however, as we already noted, argues that while Islamic terrorists use religion in distinctive ways to motivate adherents, Islamist terrorists are much like other terrorists in that their immediate objectives are political. ${ }^{51}$

We do not attempt to resolve the debate about the uniqueness of Islam with respect to terrorism here. Rather we hone in further on the theory of political motivation of extremists that we developed with respect to our first hypothesis. If a minority religion (Islam included) is a readily available platform that can be politicized by extremists, the next question is what circumstances make the politicization of religion more or less likely? The politicization of religion resulted in wars between distinct cultures, which were designated in part on the basis of religious differences. ${ }^{52}$ In empirical testing, however, this idea has not been borne out either locally or globally. ${ }^{53}$

In contrast, Fox found that most religious violence is intra-group instead of inter-group. ${ }^{54}$ Building on Fox, we suggest that it is not absolute religious distance (or difference) between families of religions that engenders the greatest potential for mobilizing group members for radical action. Instead, we argue that an extreme faction within an ethnic group that is of a different denomination or sect than the majority group is more likely to mobilize support for radical action on religious grounds than is an extremist faction in an ethnic group whose family of religion differs from the majority. This is because, we assert, non-religious cultural traits often cut across majority and minorities in groups distinguished by denomination or sect. 
For example, Protestants and Catholics in Ireland share race and language, distinguishing themselves primarily by denomination. In contrast, Turks in Germany differ from the majority by family of religion, race, and language. Consequently, when alternate cultural issues on which groups may mobilize cut across majority and minority groups, religious differences are likely to come to the fore. Thus, we propose that:

H2: When excluded from access to government, extremists in ethnic groups whose religion is the same as the majority but who differ in denomination or sect, are more likely to perpetrate terrorist attacks than extremists from ethnic groups whose family of religion differs from the majority group.

\section{Testing the Effect of Political Access on Terrorism}

Ariel Merari once argued, "As terrorism is not a discipline, there can hardly be a general theory of terrorism. ... Precise and extensive factual knowledge is still grossly lacking. Much effort must still be invested in the very first stage of scientific inquiry with regard to terrorism - the collection of data." "55 After more than two decades, Merari is still right in arguing that comparative cross-national studies that investigate the incidence of terrorism are lacking. The examination of the role that religion plays in explaining terrorism in present cross-national studies is even more limited. Our paper begins to address this gap in the existing literature.

\section{Data}

In this article, we test the relative effect of access to government on the likelihood of the use of terrorism by ethnic groups belonging to different religions than the majority and by ethnic groups belonging to different denominations or sects than the majority. The ethnicity, religion, and electoral access data we use are pooled cross-sections from executive election years in all democracies with electorally active minorities from 1970 to 2004 . We use the "Ethnicity and Electoral Politics" dataset 56 for ethnic minority access to government and for the operationalization of democracy. Using the Minorities at Risk (MAR) groups, these data record minority group access to government through ethnic and non-ethnic parties, for all electorally active ethnic groups, in all democracies since $1945 .{ }^{57}$ To address criticism of the selection bias of the MAR groups, Birnir's Ethnicity and Electoral Politics dataset surveys all electorally active groups, which passed the population threshold of MAR but that were missing from the original MAR data. Following that survey, we added countries to our data for a total of 52 groups in 37 democracies. ${ }^{58}$ The unit of analysis is the electorally active ethnic minority in a given country in an election year. For each country the number of cases per election year equals the number of electorally active ethnic minority groups in that country. While we have access to electoral data going back to 1945, the terrorism data begin in 1970. The terrorism data come from the Global Terrorism Database (GTD), which includes more than 87,000 terrorist incidents from 1970-2008. The database includes information about acts of intraand inter-state terrorism by perpetrator, location, and year in addition to qualitative notes further describing the attack. Our main explanatory variables capture how long it has been since an ethnic minority group with a different religion or a different 
religious denomination or sect than the majority has had access to the government. The dependent variable is whether or not elements of that ethnic group have engaged in terrorism in an election year. A more detailed description of the operationalization of the variables appears below.

\section{Dependent Variable}

Perpetrator's ethnic group affiliation. This variable is coded through matching the perpetrator of a terrorist attack in a given year from the GTD with each ethnic group that is included for a given country every election year. One challenge with using perpetrator information with regard to terrorism data is that in many cases the perpetrators are unknown, whether because they want to remain anonymous, because multiple groups claim responsibility, or because press reporting is unavailable or spotty. In the GTD overall, about $40 \%$ of the cases contain perpetrator information. However, in our sample, the rate of perpetrator identification is $70 \%$. While we do not examine the reason for this difference, it may be that ethnic minorities in democracies that commit terrorist acts are more likely to acknowledge that they were the perpetrators in order to influence the population and the government.

A team of coders examined all of the terrorist events contained in the GTD for the countries and election years in the Ethnicity and Electoral Politics dataset to determine whether any of the attacks could be attributed to the minority groups listed for each country. If so, the observation was coded 1, if not it was coded zero. A code of zero was also recorded if there was no terrorist attack whatsoever in a given year. If the perpetrator information was unknown for any of the attacks in a given year, then the perpetrator's group affiliation variable was coded as missing, and the case was excluded from the analysis.

\section{Independent Variables}

Ethnic minority access to government. The main explanatory variables were coded specifically for this analysis and are drawn from two existing datasets. The first is Birnir's ${ }^{59}$ Ethnicity and Electoral Politics dataset described above. We used her access variable, which measures the number of years since a minority group was last represented in the executive cabinet by an ethnic party. ${ }^{60}$ As Birnir describes, the count "starts either at democratization... or the election in which the group enters national electoral competition if that occurs later than democratization" and "the count is reset to 0 each year the group is represented by the ethnic party in the cabinet." 61 Because of these coding rules, the sample is restricted from the possible 637 observations to 400, about three-fourths of which also have values for the dependent variable.

The second dataset upon which the primary explanatory variables draw is a detailed coding of religious minority and majority group creeds and denominations by Fox. ${ }^{62}$ We use Birnir and Satana's ${ }^{63}$ original contribution to Fox's coding, which is to code the context of majority/minority group religious identity combination variables by country. According to Fox, if $80 \%$ of the ethnic minority subscribes to a different religion than the majority, the ethnic group belongs to a minority religion and is coded as such. This distinction pertains to both different religious families and different denominations within the same family. We supplement Fox's 
data with the World Directory of Minorities ${ }^{64}$ so that all of the groups in our dataset are classified. ${ }^{65}$ The various religions that are included are: Animism, Baha'ism, Buddhism, Confucianism, Christianity, Hinduism, Islam, Jainism, Judaism, Shinto, Sikhism, Taoism, and Zoroastrianism. ${ }^{66}$

We created two dummy variables that indicate whether or not a minority ethnic group's religion is the same as the majority religion and, if it is the same, whether or not the minority group religion belongs to the same religion but a different denomination or sect than the majority population. For example, in Bulgaria the ethnic majority is Christian Orthodox while the Muslim/Turkish minority is Sunni Muslim. Thus, the Turkish minority in Bulgaria is coded as belonging to a different religion than the majority of Bulgarians. On the other hand, Catholics in the U.K. are coded as belonging to the same religion as the majority Protestants as they are both Christian denominations. ${ }^{67}$

In the overall sample, there are 426 cases in which the minority ethnic group is the same religion as the majority and 211 cases in which it differs. However, once taking into account the coding restrictions and missing data, for the cases included in the analysis, there are 195 cases in which the minority and majority ethnic groups are of the same and 94 in which their religion differs. In addition, there are 72 cases in which the minority is of the same religion but of a different denomination or sect than the majority in the sample as a whole; however, only 40 of these cases appear in the analysis. See the appendix for a list of groups by country and their religious family and denomination differences from the majority.

Since we want to test the impact of excluding religious minority groups from the government on their likelihood of engaging in terrorism, we interacted the years since the group had access to the cabinet through an affiliated ethnic party with each of the two religious difference variables, separately. Since the religious difference variables are both binary, we do not encounter the problems with interpretation associated with continuous interaction terms in logit regressions. ${ }^{68}$ Our interacted variables, "Years religious minority has been out of cabinet" and "Years different denomination or sect minority has been out of cabinet," denote whether the group is a religious minority (different religion or same religion, different denomination or sect) and if so, how many years it has been out of the cabinet. If it is not a religious minority or it is in the cabinet, it is coded as 0 . The maximum length of time out of the cabinet differs substantially between minorities of a different religion than the majority (33 years) and minorities of a different denomination than the majority (57 years). Consequently, we did not standardize the independent variables.

\section{Control Variables}

We posit that all ethnic minority groups are constrained by exogenous factors such as the political institutions and economic conditions of the countries in which they live. According to Varshney, these control variables account for a large part of religious grievances and political violence. ${ }^{69}$ Conversely, Piazza argues that the usual suspects such as poverty, inequality, and poor economic development are poor predictors of political violence, specifically terrorism. ${ }^{70} \mathrm{He}$ argues that "social cleavage" theories are more likely to explain the incidence of terrorism. Accordingly, we control for institutional factors most commonly cited in the literature on ethnic minorities, coalition formation, and terrorism. ${ }^{71}$ More specifically, we include two variables accounting for presidential systems and semi-presidential systems, with the reference 
category being parliamentary systems. We also include two electoral variables accounting for countries that use proportional representation and mixed electoral systems, with the reference category being plurality or majority electoral systems. ${ }^{72}$ Similarly, economic prosperity is thought to influence the likelihood of terrorism. ${ }^{73}$ To measure economic effects we include variables accounting for GDP per capita and aggregate growth of GDP per capita. ${ }^{74}$ Finally, because India has several groups that have engaged in terrorism among the cases in the dataset, Sri Lanka has had a particularly active violent ethnic group of a different religion than the majority and the United Kingdom also had a particularly violent ethnic group of a denominational minority that has a long history of exclusion from governing coalitions, we included dummies for each of these countries to make sure that their presence was not driving any potential results. Summary statistics of the variables are listed in Table 1.

\section{Results}

As our dependent variable is binary - whether or not a group engaged in terrorism in an election year - it is appropriate to use logit regression to test our hypotheses, and the results of the analysis are displayed in Table 2 . They provide substantial support for our first hypothesis and qualified support for the second one. In the best controlled specifications (models 1-3, and 8), the greater the number of years since a religious minority group has had access to the cabinet, the greater the likelihood that it will engage in terrorism in an election year. Simply being of a different religion or

Table 1. Descriptive statistics

\begin{tabular}{|c|c|c|c|c|c|}
\hline & Obs & Mean & $S D$ & Min & Max \\
\hline Terrorist attack by group & 489 & 0.25 & 0.43 & 0 & 1 \\
\hline $\begin{array}{l}\text { Years religious minority } \\
\text { has been out of cabinet }\end{array}$ & 400 & 2.19 & 5.57 & 0 & 33 \\
\hline $\begin{array}{l}\text { Years different denomination/sect } \\
\text { minority out of cabinet }\end{array}$ & 400 & 1.24 & 6.31 & 0 & 57 \\
\hline Group years out of cabinet & 400 & 7.71 & 11.19 & 0 & 57 \\
\hline $\begin{array}{l}\text { Majority and minority of } \\
\text { different religion }\end{array}$ & 637 & 0.33 & 0.47 & 0 & 1 \\
\hline $\begin{array}{l}\text { Majority and minority same } \\
\text { religion, different branch }\end{array}$ & 637 & 0.11 & 0.32 & 0 & 1 \\
\hline India & 637 & 0.13 & 0.33 & 0 & 1 \\
\hline Sri Lanka & 637 & 0.03 & 0.16 & 0 & 1 \\
\hline United Kingdom & 637 & 0.04 & 0.21 & 0 & 1 \\
\hline Proportional representation & 637 & 0.43 & 0.50 & 0 & 1 \\
\hline Mixed & 637 & 0.12 & 0.33 & 0 & 1 \\
\hline Presidential & 637 & 0.23 & 0.42 & 0 & 1 \\
\hline Semi-presidential & 637 & 0.20 & 0.40 & 0 & 1 \\
\hline GDP per capita & 628 & 8375.71 & 8061.10 & 334.42 & 39722.25 \\
\hline Aggregate growth of GDP per capita & 623 & 2.12 & 6.26 & -20.88 & 60.39 \\
\hline
\end{tabular}

Obs $=$ observations 


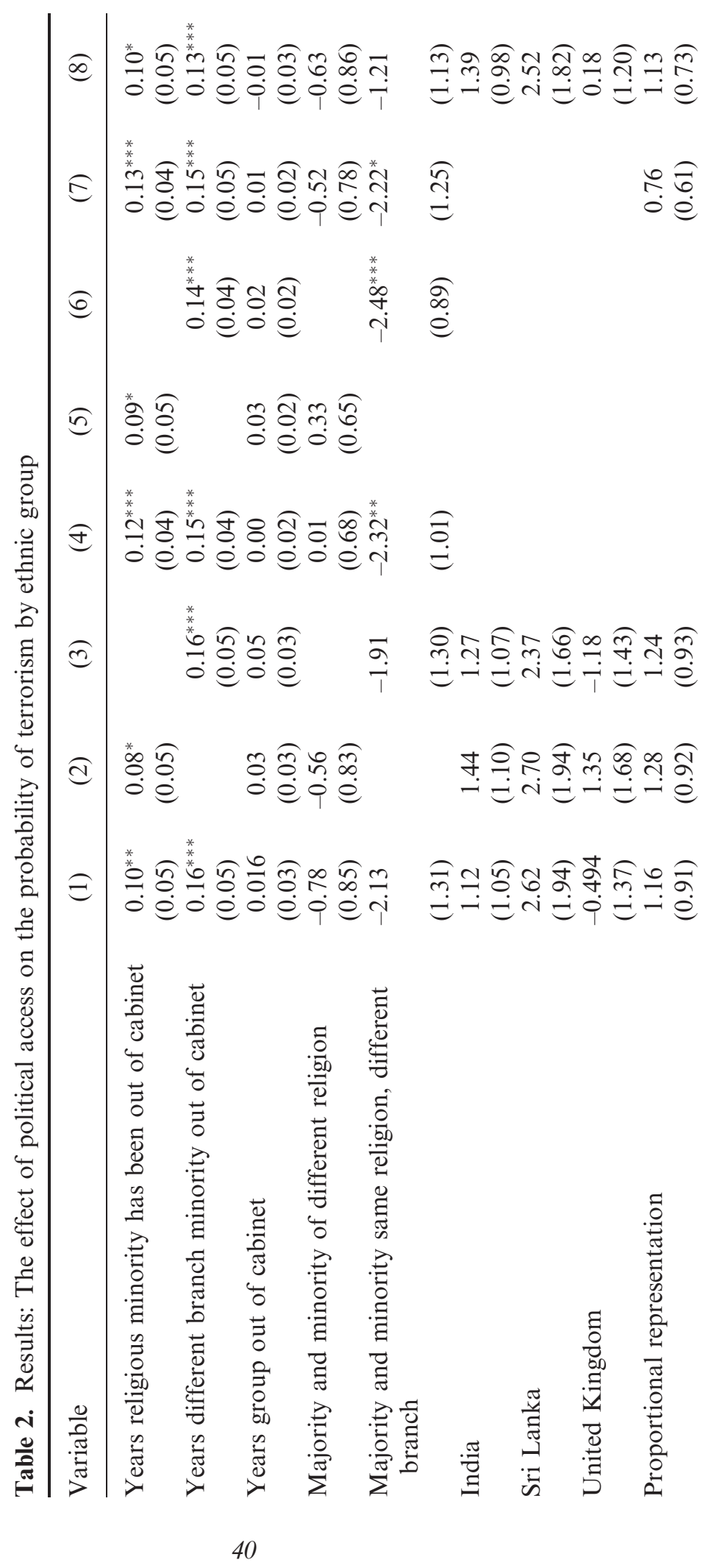


商

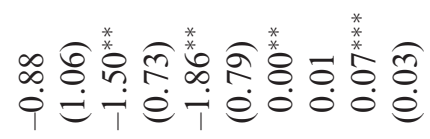

if

है.

गे

菳寻

गे है

菊守

ते है

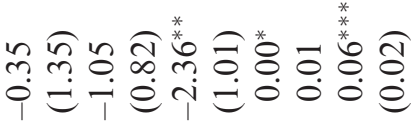

i.

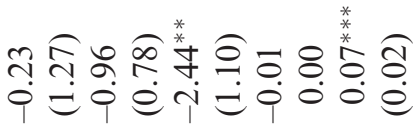

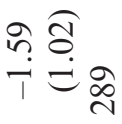

官

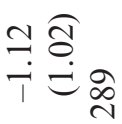

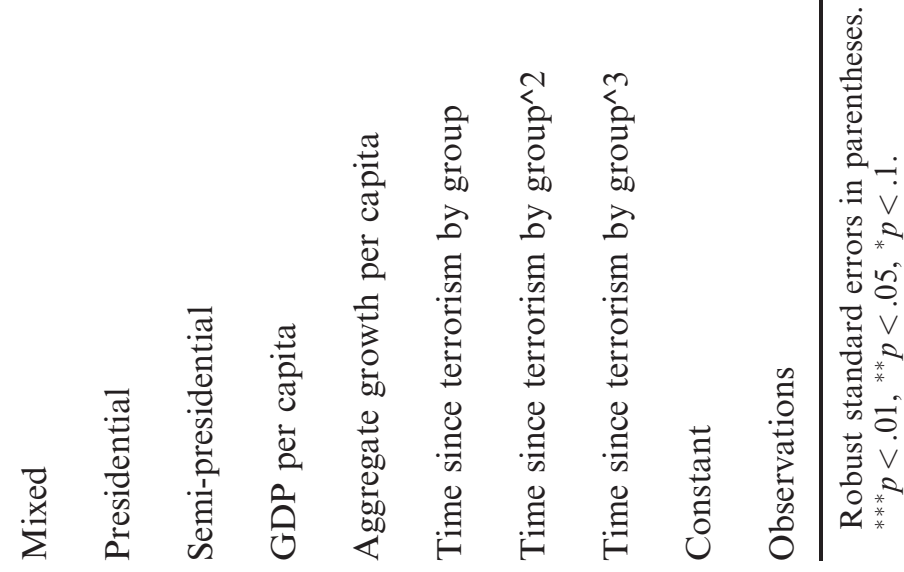


sect has no effect nor does simply being excluded from the cabinet. When controlling for institutions and unusual country effects, it is the combination of these two criteria which make terrorist violence more likely. These results for the two main explanatory variables are both substantively and statistically significant. ${ }^{75}$ Both being of a different religion than the majority and being of a different denomination or sect than the majority while also being excluded from the cabinet cause some elements of ethnic groups to be more likely to engage in terrorist violence. In model 8 , we use a cubic polynomial model ${ }^{76}$ to account for temporal autocorrelation and find that the results are neither substantively nor statistically different from model 1 upon which the following analysis is based.

Examining the predicted probabilities allows us to assess how the probability of extremists engaging in terrorism varies the number of years an ethnic group is excluded from the cabinet, whether or not it is a religious minority, and whether it is excluded from the government. All of the predicted probabilities that we present here were calculated using a method, which allows us to fix values for the variables of interest, namely religious difference and denomination/sect difference, and to vary the values of the control variables according to their true values to obtain more accurate results. ${ }^{77}$ Groups of a different religion than the majority that have not been excluded from the cabinet have a probability of 0.16 of engaging in terrorism, while those that have been excluded for 33 years, the maximum for this category, have a probability of 0.76 of engaging in terrorism as shown in Figure 1. Interestingly, the initial likelihood of having elements of ethnic minority groups of the same religion as the majority engage in terrorist violence when not excluded from the government (with a predicted probability of 0.24 ) is actually higher than that of a different religion. However, while the likelihood of elements of excluded ethnic groups of the same religion as the majority engaging in terrorist violence increases as the number of years excluded increases, the rate is much lower than for groups of a different religion. When excluded from the cabinet for 57 years, the maximum for this category, ethnic groups of the same religion as the majority have only a 0.41 probability of being associated with terrorism.
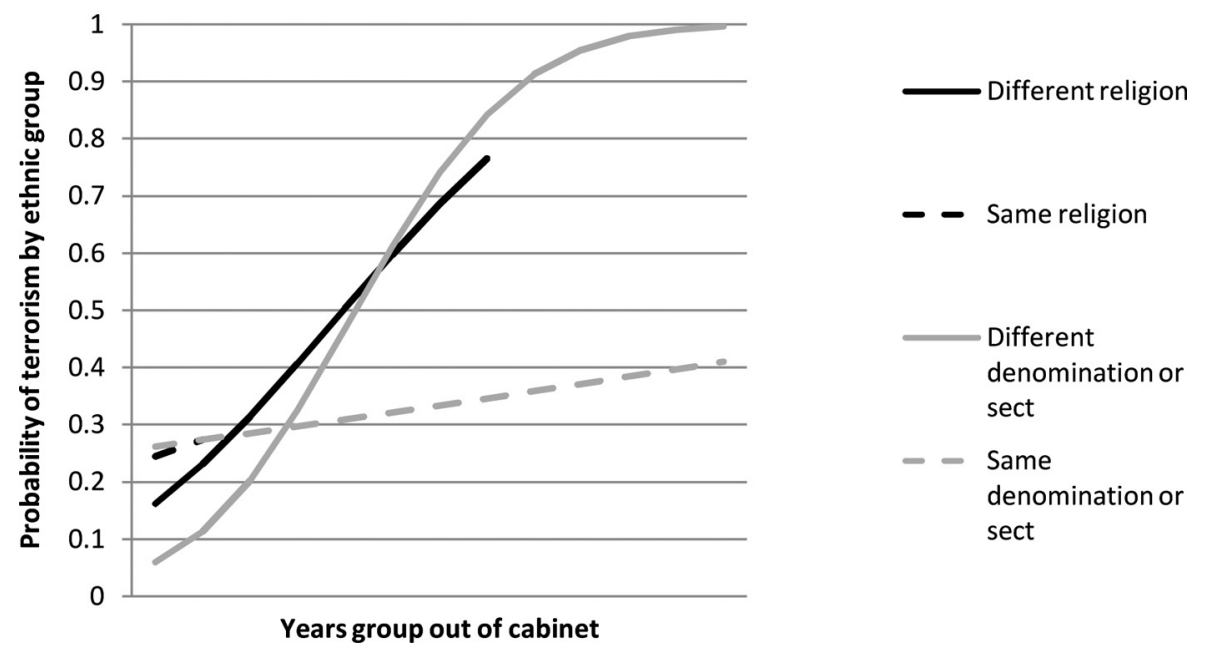

Figure 1. Political access and the probability of terrorism by the ethnic group. 
Likewise, exclusion from the cabinet of ethnic groups that are of the same religion as the majority, but differ in terms of denomination or sect, also increases the likelihood of terrorist violence, controlling for other variables. The predicted probabilities are also useful for assessing the effect of duration of government exclusion on the likelihood of terrorism for minorities of a different religious denomination or sect as well as those of the same denomination or sect across the range of the variable. When ethnic groups that differ in denomination or sect have not been excluded from the cabinet, they have about a .06 probability of engaging in terrorism, which is 0.10 less than that of groups with a different religion that have not been excluded. In looking at ethnic groups that are of the same denomination or sect as the majority, their probability of some element engaging in terrorism is higher than both of the different groups when not excluded from the cabinet, with a predicted probability of 0.26 - similar to that of same religion. However, as exclusion occurs, the probability of terrorist violence increases rapidly for groups with a different denomination or sect. When a minority ethnic group of a different denomination or sect has been excluded from the cabinet for 57 years, the maximum for this variable in this sample, it has a predicted probability of 0.99 of engaging in terrorism. When a minority ethnic group of the same denomination or sect has been excluded from the government for 57 years, its probability of being associated with terrorist violence is only 0.41 .

The predicted probabilities for these four cases are displayed in Figure 1. Exclusion of both groups increases the likelihood of terrorist violence, with the rate for groups of a different denomination or sect being greater than that for groups of a different religion, consistent with our theory. Additionally, there also appears to be a threshold effect for the excluded ethnic groups of a different sect or denomination. Just past the mid-range of the variable, at about 33 years out of the cabinet, the probability of terrorism is already at 0.84 and then increases to 0.99 over the remaining 24 years represented. ${ }^{78}$ Conversely, the slope for the predicted probabilities for ethnic groups of a different religion that are excluded from the cabinet engaging in terrorism is much closer to linear, increasing more or less steadily over the range of the variable which is $0-33$ years. This lends support to our hypotheses, particularly the second one. While exclusion of both types of groups increases the likelihood of terrorism, it would appear that excluded groups of a different sect or denomination are more easily co-opted for violent action.

Exclusion of groups which share a religious affiliation with the majority, whether of the same religion or same denomination or sect, does not have nearly the same impact on the likelihood of terrorist violence. While there is a slightly positive change, groups of the same religion that are excluded from the cabinet for 57 years have about a 0.17 probability of having elements that engage in terrorist violence, while groups of the same denomination or sect that are excluded for 57 years have about a 0.15 probability of being associated with terrorist violence. Unfortunately, the conservative nature with which we have coded the dependent variable and the problem of missing data preclude us from being able to judge the statistical significance of this difference in probabilities for terrorism between groups of a different religion and groups of a different denomination or sect across the range of the variables. However, the trend is clear from the graph and we propose that this is a fruitful venue for further empirical study with more and better data.

In terms of the control variables, both presidential and semi-presidential systems in both models generally decrease the likelihood that a group will engage in terrorism 
as compared to a parliamentary system, although the coefficients do not reach statistical significance in all of the models. The logic behind this finding is not theorized here, but it may be that the groups perceive their inclusion or exclusion differently in different systems and thus act or fail to act based on a different set of expectations. Alternatively, it may be that the religious cleavage is less salient in presidential systems even when groups are excluded. From a limited examination of the data, it does not appear that minority religious groups are more likely to be included in the cabinet in presidential or semi-presidential systems. Further research into this finding may yield important insights but are beyond the scope of the current inquiry.

The type of electoral system, whether proportional representation, first-past-thepost (comparison category), or some combination of the two (mixed), does not appear to have an effect on the likelihood that ethnic groups adhering to a minority religion or sect will engage in terrorism. Wealth is negatively related to domestic terrorist attacks but only reaches statistical significance in some of the models. Aggregate growth per capita, however, is statistically significant and positively related to the probability of terrorist incidents across models. While personal poverty is not thought to drive domestic terrorism, there is no consensus in the literature about the effects of aggregate economic conditions on the probability of terrorism. ${ }^{79}$ Importantly, our sample only includes democracies with electorally active minorities and is therefore not a representative sample with respect to the effect of economic conditions on the incidence of terrorism in democracies or worldwide. Consequently, we refrain from speculating and simply submit that this is an open venue for further study.

\section{Discussion and Conclusion}

There has been much debate in recent years about the relationship between religion and terrorism, most of it based on case studies. Moreover, the new terrorism literature has singled out Islam as a religion that breeds violence. ${ }^{80}$ Birnir, on the other hand, argues that ethnic minorities are not inherently violent; it is grievances such as the lack of access to legislative coalitions, which make minorities more likely to rebel. $^{81}$

We build on the theoretical insights of the new terrorism literature about the motivational aspects of religion and incorporate key findings from the literature on electoral politics. We propose that all minority religions provide an organizational platform that can be politicized by extremists under conditions of electoral exclusion. Furthermore, drawing on the findings of the conflict literature, we suggest that absolute religious distance is not the strongest minority motivator. Instead, we maintain that where religion is a predominant minority identifier - as is often the case where differences in denomination or sect distinguish a minority - the probability of extremist violence under conditions of political exclusion is augmented.

To empirically test our hypotheses, we explored how access to the government by ethnic minorities that subscribe to a different religion than the majority population and those that subscribe to a different denomination or sect of the same religion impacts the minority groups' propensity to engage in terrorism. We find that in both cases, lack of access to the cabinet increases the likelihood that minority groups whose religion, denomination, or sect differs from the majority group will engage in terrorism. In addition, we find that the probability of violence increases as the number of years the group is excluded increases. Looking at the extreme cases of the 
explanatory variable in the models highlights our findings: in the cases of groups with a different religion than the majority, the group that was excluded for the greatest number of years (33) was the Sri Lankan Tamils, while for different denomination, the group excluded the longest (57 years) was the Catholics in Northern Ireland. These two groups have also had notoriously active terrorist wings. ${ }^{82}$

A somewhat surprising finding in our study is that ethnic groups of the same religion, denomination, or sect have a higher initial likelihood of being associated with terrorist violence when they are not excluded from the government than do those whose religion, denomination, or sect differs. Additionally, minority ethnic groups of a different denomination or sect than the majority have the lowest likelihood of extremist elements engaging in terrorism when the group is not excluded. Future research should explore these patterns more deeply by focusing on the relationship between exclusion from legislative coalitions and the level of violence in which groups engage in light of other grievances or incentives.

Our study of the relationship between religion, government inclusion, and the incidence of terrorism is especially relevant for the literature on elections, party politics, and political violence. When they are excluded from government, certain members of minority groups engage in violent strategies, including terrorism, to voice their political demands. This, in turn, usually leads to further exclusion, which only increases the likelihood that extremist elements will perpetrate terrorist attacks. This spiral of conflict is one with which the civil conflict literature is all too familiar. In her study of political parties in Israel, Navot argues that banning parties that have violent factions only worsens the problem. ${ }^{83}$ Parties that do not find a legal outlet for their frustration become further marginalized by the hardliners. In other words, our findings suggest that the inclusion of minorities in the government might ameliorate terrorism in some cases. On the other hand, once groups become violent due to political exclusion, banning minority parties and further excluding them from government will likely exacerbate terrorist tendencies.

\section{Notes}

1. "Iraq terror toll climbs to 100: Dozens also injured in worst day of violence of 2010," Associated Press, May 11, 2010,http://www.msnbc.msn.com/id/37057717/ns/world_newsmideast_n_africa/t/iraq-terror-toll-climbs/.

2. Ibid.

3. See Wimmer et al. for a discussion of how ethnopolitical configurations of power affect the probability of ethnic conflict. Andreas Wimmer, Lars-Erik Cederman, and Brian Min, "Ethnic Politics and Armed Conflict: A Configurational Analysis of a New Global Data Set," American Sociological Review 74, no. 2 (2009): 316-337. In late December 2010, the Iraqi parliament approved a new government including all major factions. See "Iraqi parliament approves new government,” BBC News, December 21, 2010, http://www.bbc.co.uk/news/ world-middle-east-12047721.

4. Jóhanna K. Birnir and Nil S. Satana, "Religion and Coalition Politics," Comparative Political Studies 46, no. 1 (2013).

5. Pippa Norris and Ronald Inglehart, Sacred and Secular: Politics and Religion Worldwide (Cambridge: Cambridge University Press, 2004), 201.

6. Kenneth Wald and Clyde Wilcox, "Getting Religion: Has Political Science Rediscovered the Faith Factor?," American Political Science Review 100, no. 4 (2006): 523-529.

7. Ted Robert Gurr, "Peoples against States: Ethnopolitical Conflict and the Changing World System: 1994 Presidential Address," International Studies Quarterly 38, no. 3 (1994): 347-377; Jonathan Fox, "Religious Causes of Discrimination Against Ethno-Religious Minorities," International Studies Quarterly 44, no. 3 (2000): 423-450; Jonathan Fox, Ethnoreligious 
Conflict in the Late 20th Century: A General Theory (Lanham, MD: Lexington Books, 2002); Jonathan Fox, Religion, Civilization, and Civil War: 1945 through the Millennium (Lanham, MD: Lexington Books, 2004).

8. William Riker, The Theory of Political Coalitions (New Haven: Yale University Press, 1962); A. De Swaan, Coalition Theories and Cabinet Formation (Amsterdam: Elsevier, 1973); Kaare Strom, "A Behavioral Theory of Competitive Political Parties," American Journal of Political Science 34, no. 2 (1990): 565-598; Anna Gryzmala-Busse, "Coalition Formation and the Regime Divide in East Central Europe," Comparative Politics 34, no. 1 (2001): 85-104.

9. Arend Lijphart, "The Relative Salience of the Socio-Economic and Religious Issue Dimensions: Coalition Formations in Ten Western Democracies, 1919-1979," European Journal of Political Research 10, no. 3 (1982): 201-211; Birnir and Satana (see note 4 above).

10. Indridi Indridason, "Does Terrorism Influence Domestic Politics? Coalition Formation and Terrorist Incidents," Journal of Peace Research 45, no. 2 (2008): 241-259; Leonard Weinberg, Ami Pedahzur, and Arie Perliger, Political Parties and Terrorist Groups (New York: Routledge, 2009); James A. Piazza, "Terrorism and Party Systems in the States of India," Security Studies 19, no. 1 (2010): 99-123; David C. Rapoport, "Fear and Trembling: Terrorism in Three Religious Traditions," American Political Science Review 78, no. 3 (1984): 668-672.

11. Birnir and Satana (see note 4 above).

12. Following Birnir and Satana's conceptualization, we use the term majority to refer to the ethnic majority constituency whose representative majority/plurality party controls the executive. We use ethnic minority constituency represented by minority party access (through a non-minority party).

13. Todd Sandler, "Collective Action and Transnational Terrorism," World Economy 26 (2003): 779-802, 780.

14. Birnir and Satana (see note 4 above).

15. Global Terrorism Database, START, http://www.start.umd.edu/gtd/.

16. Ernest Gellner, Postmodernism, Reason and Religion (New York: Routledge, 1992), 5.

17. Norris and Inglehart (see note 5 above), 211.

18. Pippa Norris, Electoral Engineering: Voting Rules and Political Behavior (Cambridge: Cambridge University Press, 2004). For a thorough discussion on how ethnic cleavages may stabilize votes, see Jóhanna K. Birnir, Ethnicity and Electoral Politics (New York: Cambridge University Press, 2007).

19. Geoffrey C. Layman and John C. Green, "War and Rumours of Wars: The Contexts of Cultural Conflict in American Political Behaviour," British Journal of Political Science 36, no. 1 (2005): 61-89.

20. John C. Green, "Religion and Politics in the 1990s: Confrontations and Coalitions," in Mark Silk, ed., Religion and American Politics: The 2000 Election in Context (Hartford, CT: The Pew Program on Religion and the News Media, Center for the Study of Religion in Public Life, 2000), 38, http://www.trincoll.edu/depts/csrpl/religame.pdf.

21. Ibid., 38.

22. Jason Wittenberg, Crucibles of Political Loyalty: Church Institutions and Electoral Continuity in Hungary (New York: Cambridge University Press, 2006).

23. Nancy L. Rosenblum, "Religious Parties, Religious Political Identity, and the Cold Shoulder of Liberal Democratic Thought," Ethical Theory and Moral Practice 6, no. 1 (2003): 23-53, 31.

24. Birnir (see note 18 above); Birnir and Satana (see note 4 above).

25. Arend Lijphart, Democracy in Plural Societies: A Comparative Exploration (New Haven: Yale University Press, 1977).

26. Birnir (see note 18 above).

27. Leonard Weinberg, Ami Pedahzur, and Sivan Hirsch-Hoefler, "The Challenges of Conceptualizing Terrorism," Terrorism and Political Violence 16, no. 4 (2004): 777-794.

28. Ibid., 785. See also Matthew J. Morgan, "The Origins of the New Terrorism," Parameters 34, no. 1 (2004): 29-43.

29. Importantly, there is substantial debate in the literature about the causal relationship between religion and conflict. For example, Varshney argues that seemingly religious conflicts in India can be explained by intercommunity civic engagement (or lack thereof) and are not related to ethnicity or religion per se. See Ashutosh Varshney, Ethnic Conflict and Civic 
Life: Hindus and Muslims in India (New Haven: Yale University Press, 2002), 286. Varshney posits that Hindu-Muslim violence in India is an urban phenomenon and that cities with more civic organizations are less likely to develop violent actions against the state. Following this strand of the literature, those who do not deem that the content of religion is the root cause of violence find little support for the "new terrorism" literature. Scholars who mostly work within the rational choice paradigm argue that terrorist groups are strategic actors that try to accomplish political goals through violence, regardless of their religion, ethnicity, age, or education. Martha Crenshaw, "The Psychology of Terrorism: An Agenda for the 21st century," Political Psychology 21, no. 2 (2000): 405-420; Martha Crenshaw, "The Debate over 'New' vs. 'Old' Terrorism," in Ibrahim A. Karawan, Wayne McCormack, and Stephen E. Reynolds, eds., Values and Violence: Intangible Aspects of Terrorism, Studies in Global Justice, Vol. 4 (Dordrecht: Springer Netherlands, 2009); Martha Crenshaw, Old and New Terrorism - Lessons Learned, presented at the Second IRRI Conference on International Terrorism, Wesleyan University, Middletown, CT, February 13, 2006, http://www.egmontinstitute.be/ speechnotes/06/060213-jihad.terr/crenshaw.htm; Isabella Duyvesteyn, "How New is the New Terrorism," Studies in Conflict and Terrorism 27, no. 5 (2004): 439-454; Jeffrey K. Hadden and Anson Shupe, eds, Secularization and Fundamentalism Reconsidered: Religion and the Political Order (Ottawa: University of Ottawa Press, 1998); Todd Sandler and Walter Enders, "Applying Analytical Methods to Study Terrorism," International Studies Perspectives 8, no. 3 (2007): 287-302. For example, Canetti et al.'s research reveals, "in Israel, Muslims were found to support political violence more than Jews, yet the strong role of socio-economic deprivations underscored that religion does not, in itself, engender violence." See Daphna Canetti, Steven E. Hobfoll, Ami Pedahzur, and Eran Zaidise, "Much Ado About Religion: Religiosity, Resource Loss, and Support for Political Science," Journal of Peace Research 47, no. 5 (2010): 576.

30. As quoted in Mark Sedgwick, "Al-Qaeda and the Nature of Religious Terrorism," Terrorism and Political Violence 16, no. 4 (2004): 795-814, 798. See also Bruce Hoffman, Inside Terrorism (London: Colombia University Press, 1998).

31. David C. Rapoport, "Fear and Trembling: Terrorism in Three Religious Traditions," American Political Science Review 78 (1984): 668-672.

32. For a more concise discussion of the literature, see Andreas Hasenclever and Volker Rittberger, "Does Religion Make a Difference? Theoretical Approaches to the Impact of Faith on Political Conflict," Millennium: Journal of International Studies 29 (2000): 641-674.

33. Mark Juergensmeyer, "Religion as a Root Cause of Terrorism," in Louise Richardson, ed., The Roots of Terrorism (London: Routledge, Taylor and Francis Group, 2006), 133-143.

34. Mark Juergensmeyer, Terror in the Mind of God: The Global Rise of Religious Violence (Berkeley, CA: University of California Press, 2003).

35. Jonathan Fox codes a variable for civilizational differences and tests the clash of civilizations argument. His findings do not support Huntington's argument; however, he finds that religion affects civil conflict as an intervening variable: some religions have fought more often than others and religious conflict is on the rise since around 1980.

36. Jeffrey R. Seul, "Ours is the Way of God': Religion, Identity, and Intergroup Conflict," Journal of Peace Research 36, no. 5 (1999): 553-569; Fox (see note 7 above).

37. Rodney Stark, One True God: Historical Consequences of Monotheism (Princeton, NJ: Princeton University Press, 2001), 367, 376.

38. Andreas Hasenclever and Volker Rittberger (see note 32 above).

39. Sedgwick (see note 30 above).

40. Ibid., 805 .

41. William Lee Eubank and Leonard Weinberg, "Does Democracy Encourage Terrorism," Terrorism and Political Violence 6, no. 4 (1994): 417-433.

42. Claude Berrebi and Esteban F. Klor, "On Terrorism and Electoral Outcomes: Theory and Evidence from the Israeli-Palestinian Conflict," Journal of Conflict Resolution 50, no. 6 (2006): 899-925; Weinberg et al. (see note 10 above); Piazza (see note 10 above).

43. Lars-Erik Cederman, Simon Hug, and Lutz F. Krebs, "Democratization and Civil War: Empirical Evidence," Journal of Peace Research 47, no. 4 (2010): 377-394.

44. Indridason (see note 10 above), 243. Others disagree about the role of terrorism in the outcome of the Spanish election. For example, see I.C. van Biezen, "Terrorism and Democratic Legitimacy: Conflicting Interpretations of the Spanish Elections," Mediterranean Politics 10, no. 1 (2005): 99-108. 
45. Birnir (see note 18 above).

46. Birnir and Satana (see note 4 above).

47. Indridason (see note 10 above), 243.

48. Juergensmeyer (see note 33 above); Sedgwick (see note 30 above).

49. Gabriel Ben-Dor and Ami Pedahzur, "The Uniqueness of Islamic Fundamentalism and the Fourth Wave of International Terrorism," in Leonard Weinberg and Ami Pedahzur, eds., Religious Fundamentalism and Political Extremism (London: Frank Cass, 2004), 71-91.

50. Ibid., 86.

51. Sedgwick (see note 30 above).

52. Ted G. Jelen and Clyde Wilcox, eds., Religion and Politics in Comparative Perspective: The One, the Few, and the Many (New York: Cambridge University Press, 2002); Samuel P. Huntington, The Clash of Civilizations and the Remaking of World Order (New York: Simon \& Schuster, 1996); Seul (see note 36 above); Stark (see note 37 above).

53. Fox (see note 7 above); Giacomo Chiozza, "Is There a Clash of Civilizations? Evidence from Patterns of International Conflict Involvement, 1946-97," Journal of Peace Research 39, no. 6 (2002): 711-734; Tanja Ellingsen, "Colorful Community or Ethnic Witches' Brew? Multiethnicity and Domestic Conflict during and after the Cold War," The Journal of Conflict Resolution 44, no. 2 (2000): 228-249; Erik Gartzke and Kristian Skrede Gleditsch, "Identity and Conflict: Ties that Bind and Differences that Divide," European Journal of International Relations 12, no. 1 (2006): 53-87; Errol A. Henderson, "Culture or Contiguity? Ethnic Conflict, the Similarity of States, and the Onset of Interstate War, 1820-1989," Journal of Conflict Resolution 41, no. 5 (1997): 649-668; Errol A. Henderson, "Mistaken Identity: Testing the Clash of Civilizations Thesis in Light of the Democratic Peace Claims," British Journal of Political Science 34, no. 3 (2004): 539-563; Errol A. Henderson, "Not Letting the Evidence Get in the Way of Assumptions: Testing the Clash of Civilizations with More Data," International Politics 42, no. 4 (2005): 458-469; Errol A. Henderson and David Singer, "Civil War in the Post-Colonial World, 1946-92," Journal of Peace Research 37, no. 3 (2000): 275-299; Andrej Tusicisny, "Civilizational Conflicts: More Frequent, Longer and Bloodier?," Journal of Peace Research 41, no. 4 (2004): 485-498. To be clear, authors testing both at the inter-state and intra-state levels do find some association between religion and conflict but their theoretical expectations differ from Huntington's. For example, Fox suggests that religion becomes a salient political issue when the group harbors desires for autonomy or independence and concludes that religion affects domestic conflict as an intervening variable.

54. Fox (2002, see note 7 above).

55. Cited in Alex Schmid and Albert Jongman, Political Terrorism: A New Guide to Actors, Authors, Concepts, Databases, Theories and Literature (Oxford: North Holland, 1988), 179.

56. Birnir (see note 18 above).

57. MAR. 2004, http://www.cidcm.umd.edu/inscr/mar/.

58. Birnir's universe of cases is based on the Minorities at Risk (MAR) data and includes coalition information for 70 groups in 39 democracies, from 1945 to 2004. To isolate the effect of ethno-nationalism Birnir excludes Muslims in India and Hindus in Bangladesh from her sample because MAR classifies these groups as religious groups. Both are electorally active and Birnir and Satana have added them to their sample. Furthermore, Birnir surveys all electorally active ethnic minorities that she argues should be included in MAR because they meet all the criteria of large (over 1\% of population or 100,000) "Minorities at Risk." Birnir and Satana have added the groups that are reportedly electorally active. They also take ethnic representation in the cabinet through a non-ethnic party as sufficient evidence of minority group mobilization. This is in contrast to Birnir who also requires that an ethnic party run candidates in elections. To keep with the definition of democracy, Fiji is eliminated.

59. Birnir (see note 18 above).

60. Although Birnir (see note 18 above) and Birnir and Satana (see note 4 above) use the years since the minority ethnic group has had any representation in the cabinet whether through a member of an ethnic party or a member of the ethnic minority who is a member of a non-ethnic party, we chose to focus exclusively on the exclusion of the ethnic party as we think it sends a clearer signal. However, we ran our analysis using the more inclusive independent variable, representation in the cabinet through ethnic party or ethnic minority member not from an ethnic party, and the results were substantively the same. 
61. Birnir (see note 18 above), 174.

62. Fox (see note 7 above).

63. Birnir and Satana (see note 4 above).

64. Minority Rights Group International, World Directory of Minorities (London: Author, 1997).

65. Following Birnir and Satana, we have included Bosnia and Herzegovina where the plurality (48\%) is Bosniak (Sunni Muslim) but Croats (Catholic) and Serbs (Orthodox) are minorities. In contrast, Fox classifies Bosnia and Herzegovina's majority as "Islam, Other or Mixed."

66. For further classification, see for example: http://www.adherents.com/.

67. Birnir and Satana find that "in a few cases Fox classifies the minority group as belonging to various denominations." In those cases they coded the variable as 0. Birnir and Satana state that "in only two categories do electorally active minorities share a religious family but differ in denomination from the majority. These categories are Christian/Christian and Islam/ Islam. In many more cases, where there are differences, the majority and the minority belong to different creeds. In three cases (Bangladesh, Bolivia, and Venezuela) minorities subscribe to both different and the same creeds as the majority. In Bolivia and Venezuela some of the indigenous are Shamanist but most are Catholic and were coded as belonging to the same creed and denomination as the majority. In Bangladesh, however, the Chittagong Hill tribes include both Muslim and Hindu populations. Furthermore, Muslim Chittagongs are Shi'i while the ethnic majority in Bangladesh is Sunni. Consequently, the Chittagong Hill tribes are coded as both belonging to a different creed and a different denomination than the majority."

68. C. Ai and E. C. Norton, "Interaction Terms in Logit and Probit models," Economics Letters 80, no. 1 (2003): 123-129; E. C. Norton, H. Wang, and C. Ai, "Computing Interaction Effects and Standard Errors in Logit and Probit Models," Stata Journal 4 (2004): 154-167.

69. Varshney (see note 29 above).

70. James A. Piazza, "Rooted in Poverty?: Terrorism, Poor Economic Development and Social Cleavages," Terrorism and Political Violence 18, no. 1 (2006): 159-177.

71. Donald Horowitz, Ethnic Groups in Conflict (Berkeley, CA: California University Press, 1985); Donald Horowitz, "Making Moderation Pay," in Joseph Montville, ed., Conflict and Peacekeeping in Multiethnic Societies, (New York: Lexington Books, 1990), 451-475; Stephen M. Saideman, David Lanoue, Michael Campenni, and Samuel Stanton, "Democratization, Political Institutions, and Ethnic Conflict: A Pooled, Cross-Sectional Time Series Analysis from 1985-1998," Comparative Political Studies 35, no. 1 (2002): 103-129; Birnir (see note 18 above); Piazza (see note 70 above); Piazza (see note 9 above).

72. We used IDEA's data on electoral systems. See International Institute for Democracy and Electoral Assistance (IDEA) at http://www.idea.int/vt/index.cfm.

73. Piazza (see note 70 above).

74. Alan Heston, Robert Summers, and Bettina Aten. Penn World Table Version 6.3. Center for International Comparisons of Production, Income and Prices at the University of Pennsylvania (CICUP), 2009.

75. The standard errors are clustered on group, but the results were nearly identical when the regression was run with the standard errors clustered on country.

76. D.B. Carter and C. S. Signorino. "Back to the Future: Modeling Time Dependence in Binary Data." Political Analysis 18, no. 3 (2010): 271-292.

77. Michael J. Hanmer and K. Ozan Kalkan, Behind the Curve: Clarifying the Best Approach to Calculating Predicted Probabilities and Marginal Effects from Limited Dependent Variable Models (University of Maryland Working Paper, 2009).

78. We checked to see if this relationship could be driven by a single case and this was not the case.

79. Alan B. Krueger and David D. Laitin, "Kto Kogo?: A Cross Country Study of the Origins and Targets of Terrorism," in Philip Keefer and Norman Loayza, eds., Terrorism, Economic Development and Political Openness (New York: Cambridge University Press, 2008), 148-173.

80. Bruce Hoffman, "Holy Terror": The Implications of Terrorism Motivated by a Religious Imperative, 1993, http://www.rand.org/pubs/papers/2007/P7834.pdf; Hoffman (see note 30 above); David G. Kibble, “The Attacks of 9/11: Evidence of a Clash of Religions?" Parameters (Autumn 2002): 34-45; http://www.carlisle.army.mil/usawc/parameters/Articles/02autumn/ kibble.pdf; Laurence A. Dobrot, The Global War on Terrorism: A Religious War? (Carlisle 
Barracks, PA: Strategic Studies Institute, U.S. Army War College, November 2007), http:// www.strategicstudiesinstitute.army.mil /pdffiles/pub822.pdf; David C. Rapoport, "The Four Waves of Rebel Terror and September 11," Anthropoetics 8, no. 1 (2002), http://www. anthropoetics.ucla.edu/ap0801/terror.htm; Morgan (see note 28 above).

81. Birnir (see note 18 above).

82. The data account for self-exclusion of groups from the parliamentary elections. We first assess electoral activity of groups by year, and political parties (those having both violent and non-violent wings). Then we code for the access of the minority political parties that have run in the elections. Thus, the analysis is based on those groups who chose to participate in elections and have the opportunity of inclusion in the cabinet. Finally, we do not have the ability to account for groups who may have been invited but refused to join a governing coalition after they were elected to parliament. Given well-accepted assumptions about the benefits of joining governments, we do not believe this is a substantial problem with the data.

83. Suzie Navot, "Fighting Terrorism in the Political Arena: The Banning of Political Parties," Party Politics 14, no. 6 (2008): 745-762. Also see John Finn, "Electoral Regimes and the Proscription of Anti-Democratic Parties," Terrorism and Political Violence 12, no. 3 (2000): 51-77, for a discussion of under which circumstances parties are banned in democracies for regime stability.

\section{Appendix: Summary of Countries and Groups included in the Analysis}

\begin{tabular}{llcc}
\hline Country & \multicolumn{1}{c}{ Group } & $\begin{array}{c}\text { Different religious } \\
\text { family? }\end{array}$ & $\begin{array}{c}\text { Different } \\
\text { branch? }\end{array}$ \\
\hline Albania & Greeks & 1 & 0 \\
Australia & Aborigines & 0 & 0 \\
Bangladesh & Chittagong Hill Tribes & 1 & 0 \\
Bangladesh & Hindus & 1 & 0 \\
Belgium & Francophones & 0 & 0 \\
Bolivia & Indigenous Highland Peoples & 1 & 0 \\
Bolivia & Lowland Indigenous Peoples & 1 & 0 \\
Bosnia & Croats & 1 & 0 \\
Bosnia & Muslims & 0 & 0 \\
Bosnia & Serbs & 1 & 0 \\
Bulgaria & Roma & 0 & 0 \\
Bulgaria & Turks & 1 & 0 \\
Canada & Quebecois & 0 & 1 \\
Colombia & Blacks & 0 & 0 \\
Colombia & Indigenous Peoples & 0 & 0 \\
Croatia & Serbs & 0 & 1 \\
Czech Rep. & Roma & 0 & 0 \\
Ecuador & Indigenous Highland Peoples & 0 & 0 \\
Estonia & Russians & 0 & 1 \\
Finland & Swedish-Speaking & 0 & 0 \\
Georgia & Abkhazians & 1 & 0 \\
Germany & Turks & 1 & 0 \\
Ghana & Ashanti & 0 & 0 \\
Greece & Muslims & 1 & 0 \\
Hungary & Roma & 0 & 0 \\
India & Assamese & & 0 \\
\hline
\end{tabular}




\begin{tabular}{|c|c|c|c|}
\hline Country & Group & $\begin{array}{l}\text { Different religious } \\
\text { family? }\end{array}$ & $\begin{array}{c}\text { Different } \\
\text { branch? }\end{array}$ \\
\hline India & Kashmiris & 1 & 0 \\
\hline India & Mizos & 1 & 0 \\
\hline India & Muslims & 1 & 0 \\
\hline India & Nagas & 1 & 0 \\
\hline India & Scheduled Castes & 0 & 0 \\
\hline India & Scheduled Tribes & 0 & 0 \\
\hline India & Sikhs & 1 & 0 \\
\hline Indonesia & Chinese & 1 & 0 \\
\hline Israel & Arabs & 1 & 0 \\
\hline Israel & Russians & 0 & 0 \\
\hline Italy & Sardinians & 0 & 0 \\
\hline Italy & South Tyrolians & 0 & 0 \\
\hline Latvia & Russians & 0 & 1 \\
\hline Lithuania & Russians & 0 & 0 \\
\hline Macedonia & Albanians & 1 & 0 \\
\hline Macedonia & Roma & 0 & 0 \\
\hline Macedonia & Serbs & 0 & 0 \\
\hline Madagascar & Merina & 0 & 0 \\
\hline Malawi & Lomwe & 0 & 0 \\
\hline Malawi & Nyanja-Speakers & 0 & 0 \\
\hline Malawi & Tumbuka-Speakers & 0 & 0 \\
\hline Malawi & Yao & 1 & 0 \\
\hline Moldova & Gagauz & 0 & 0 \\
\hline Moldova & Slavs & 0 & 0 \\
\hline Namibia & Basters & 0 & 0 \\
\hline Namibia & East Caprivians & 0 & 0 \\
\hline Namibia & Europeans & 0 & 0 \\
\hline Nepal & Terai & 1 & 0 \\
\hline Nepal & Tibeto-Burman & 1 & 0 \\
\hline New Zealand & Maori & 0 & 0 \\
\hline Nigeria & Ibo & 1 & 0 \\
\hline Nigeria & Yoruba & 0 & 0 \\
\hline Pakistan & Baluchis & 0 & 0 \\
\hline Pakistan & Mohajirs & 0 & 0 \\
\hline Pakistan & Pashtuns (Pushtuns) & 0 & 0 \\
\hline Pakistan & Sindhis & 0 & 0 \\
\hline Peru & Indigenous Highland Peoples & 0 & 0 \\
\hline Poland & Germans & 0 & 0 \\
\hline Romania & Magyars (Hungarians) & 0 & 1 \\
\hline Romania & Roma & 0 & 0 \\
\hline S Korea & Honamese & 0 & 0 \\
\hline Slovakia & Hungarians & 0 & 1 \\
\hline Slovakia & Roma & 0 & 0 \\
\hline South Africa & Asians & 1 & 0 \\
\hline South Africa & Black Africans & 0 & 0 \\
\hline
\end{tabular}




\begin{tabular}{llcc}
\hline Country & \multicolumn{1}{c}{ Group } & $\begin{array}{c}\text { Different religious } \\
\text { family? }\end{array}$ & $\begin{array}{c}\text { Different } \\
\text { branch? }\end{array}$ \\
\hline South Africa & Coloreds & 0 & 0 \\
South Africa & Europeans & 0 & 0 \\
South Africa & Xhosa & 0 & 0 \\
South Africa & Zulus & 0 & 0 \\
Spain & Basques & 0 & 0 \\
Spain & Catalans & 0 & 0 \\
Sri Lanka & Indian Tamils & 1 & 0 \\
Sri Lanka & Sri Lankan Tamils & 1 & 0 \\
Switzerland & French & 0 & 0 \\
Switzerland & Italian & 0 & 0 \\
Thailand & Chinese & 0 & 0 \\
Thailand & Malay-Muslims & 1 & 0 \\
Trinidad Tobago & African Descent & 0 & 1 \\
Trinidad Tobago & Indian Descent & 1 & 0 \\
Turkey & Kurds & 0 & 0 \\
UK & Afro-Caribbeans & 0 & 0 \\
UK & Catholics In N. Ireland & 0 & 1 \\
UK & Scots & 0 & 0 \\
Ukraine & Russians & 0 & 0 \\
USA & African Americans & 0 & 0 \\
USA & Asian Americans & 1 & 0 \\
USA & Hispanic & 0 & 1 \\
Venezuela & Indigenous Peoples & 1 & 0 \\
Yugoslavia & Kosovo Albanians & 1 & 0 \\
\hline
\end{tabular}

